\section{Jurnal Hukum Volkgeist \\ Volume 5 Issue 1, Desember 2020 \\ P-ISSN : 2528-360X, E-ISSN : 2621-6159}

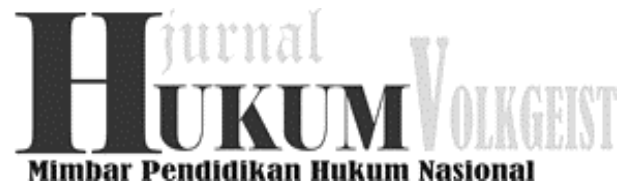

Mimbar Pendidikan Hukum Nasional

\title{
Juridical review of the authority of the Indonesian consultative assembly after the amendments to the 1945 constitution
}

\author{
Yudin Yunus $^{1}$
}

\begin{abstract}
This research discusses the Juridical Review of the Authority of the Indonesian Consultative Assembly after the 1945 Constitution Amendment. The results of the study describe the applicable provisions with the facts that occur in the community regarding the authority of the People's Consultative Assembly after the amendment of Law D1945 which is very minimal as a major State institution compared to other State institutions. The research method used in this research is normative research method. The statutory approach and the historical approach are approaches using legislation and regulations. And the historical approach is to refer to historical principles the law on the authority of the MPR prior to the amendments to the 1945 Constitution. These principles can be found in scholarly views or legal doctrines. This study aims to analyze the authority of the people's deliberative assembly before and after the amendment of the 1945 Constitution, based on the prevailing laws and legal history, namely by providing clarity on the status of the State MPR institution which is still maintained by the State as the main State institution which only has 3 post authorities. amendment e 4 In Article 3 of the Constitution, namely: 1 Amending and stipulating the Constitution, 2. Inaugurating the President and / or Vice President 3. Dismissing the President and / or Vice President during their term of office according to the Constitution. Based on the results of the research, it is concluded that the authority of the People 's Consultative Assembly after the Amendment of the 1945 Constitution is very minimal, namely only 3 powers not to mention that all of these 3 powers are only ceremonial.
\end{abstract}

Keyword : People's Consultative Assembly, the Constitution, the Authority

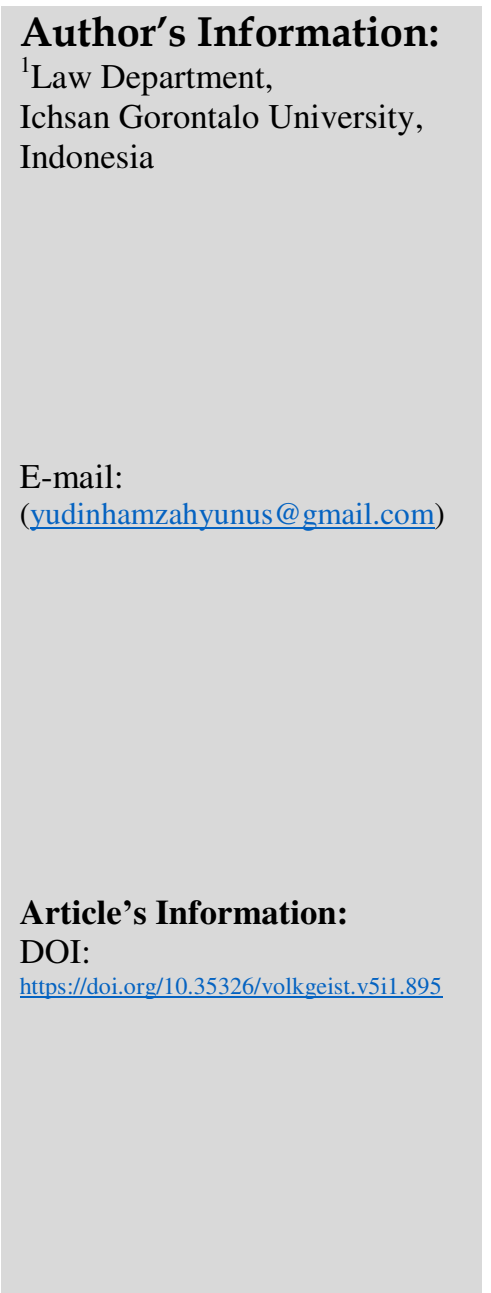

\section{Introduction}

The position and authority of the MPR as a state institution in the Indonesian constitutional system. The post-reform amendments to the 1945 Constitution have consequences for the position and authority attached to the MPR. One of the important changes in the 1945 Constitution which affected the position and authority of the MPR was a change in the form and sovereignty of the State, especially in Article 1 paragraph (2) of the Constitution. Prior to the amendment, it was stated that, "Sovereignty is in the hands of the people, and is carried out entirely by the People's Consultative Assembly " (UUD 1945). Meanwhile, after the amendment was amended, " Sovereignty rests in the hands of the people and is exercised according to the Constitution ". Significant changes can also be seen in Article 3 of the 1945 Constitution. If before the MPR amendment was given the authority to determine the Outlines of State Policy (GBHN), then after the amendment the authority was no longer given. 
In general, the implications of the amendment to the 1945 Constitution, of course, result in changes in the position and authority of the MPR as well. There are at least 3 (three) fundamental implications as a result of the amendment to the 1945 Constitution on the position and authority of the MPR, including:

a. The MPR is no longer the highest state institution as the embodiment of Article 1 paragraph 2 of the 1945 Constitution, which is an absolute representation of the sovereignty of the Indonesian people. The MPR after the amendments to the 1945 Constitution, now has an equal position with other high state institutions, namely the Presidential Institute , the House of Representatives (DPR), the Regional Representative Council (DPD), the Supreme Audit Agency (BPK), the Supreme Court and the Constitutional Court. ( Indrayana , 2004)

b. As a consequence of the MPR which is no longer the highest state institution, the MPR is not a representative institution, but tends to become a " joint session " between DPR members and DPD members which has a function as a constituent institution in charge of amending and enacting the Constitution. Implicitly, the spirit or the existence of the Assembly be held if there is or with respect to the authority granted by the Constitution of the Republic of Indonesia Year 1945. As opinions Jimly Asshidiqie stating that the organ itself MPR had said no ( actual existence) at the time the authority is being implemented. (Asshiddiqie, 2006) In the pattern of a unitary state as adopted by Indonesia, the supremacy of the parliament which holds the legislative function is only in the hands of the DPR and the DPD not in the hands of the MPR anymore.

c. MPR no longer have the authority to make provisions that are set ( regelling ). The MPR after the amendments to the 1945 Constitution was only given the authority to make beshickking decisions. The elimination of the MPR's authority to establish State Policy Guidelines, means that the basic rules of our country apply singularly or singularly based on the 1945 Constitution of the Republic of Indonesia. The MPR is no longer authorized to issue basic state rules ( grundnorm ) outside the 1945 Constitution of the Republic of Indonesia. that is regulatory.

The MPR no longer functions as the supreme body with the highest authority and without control over the comparison of the functions of this institution before and after reformation is far proportional, namely in MPR Decree No. 1 / MPR / 1978 it is said that the MPR has the task of determining the Constitution, establishing the GBHN, and electing and appointing the President and Vice President. In addition, the MPR also has the powers, namely

a. Making decisions, including GBHN, which cannot be overturned by other state institutions, which are implemented by the President

b. Provide an explanation in the form of an interpretation of the MPR decision

c. Complete the election and appoint the President and Vice President

d. Asking the President to be accountable regarding the implementation of the GBHN and assessing that accountability

e. Change the Constitution

f. Establish MPR rules 
g. To determine the MPR leadership elected from and by the members

h. Take decisions regarding members who break the oath / promise of the members . (Quarter, 2011)

And after post-reform the 4th amendment in Article 3 of the 1945 Constitution the amendment results that the MPR is authorized to:

a. Amend and stipulate the Constitution

b. Inaugurate the President and / or Vice President

c. To dismiss the President and / or Vice President during their term of office according to the Constitution.

The first and third MPR functions are not routinely performed (rarely). ( Riyanto , 2006) The function of inaugurating the President and Vice President is merely ceremonial, because the MPR is merely conducting a ceremony. It should be noted that it is no longer the MPR that elects the President and Vice President, but the people directly. Therefore, the MPR could not obstruct the inauguration process with a quorum for the presence of their members, let alone the number of votes agreeing / disagreeing with the inauguration.

Not to mention the presence of powers of parliament (DPR) that appear after the amendment of the 1945 Constitution that affect the authority of the Assembly 's Consultative Rakyat (MPR) In dismiss the President is now the House could also provide Proposed Dismissal of President To MPR ie, with the advent of 5 Task Supreme Constitutional That (Asshiddiqie, 2010) ;
a) Material Test Against the Law
b) Deciding State Institution Disputes
c) Dissolution of Political Parties
d) Deciding Election Dispute
e) Impeachment of the President

At the fifth point, namely the impeachment of the president or commonly known as Inpiechment in foreign countries. This is the authority of the Parliament In providing a proposal for dismissal of the president that is the way before giving a proposal for dismissal of the president will be given to this Decision should be tried first in the court of the Constitution, but the trial according to Jimly Assidiki as the first judge in the Court of the Constitution is a session that has the obligation to decide Proposed approval of the House of Representatives is therefore in the Written 5 Kewen an gan but in fact the task of the Court constitutional Being 4 Kewen an gan 1 obligation is 1 obliged to decide proposal D PR for Dismissal of the President.

Of 3 tasks left by the Assembly following the amendment to the Law of 1945, he has no validity with the presence kewena $\mathrm{n}$ gan of Parliament is in the process of impeachment process was highly influential on Kewen an gan MPR . ( Prodjodikoro , nd)

In the impeachment process, the Constitutional Court is obliged to provide an assessment of the DPR's opinion regarding the alleged violation by the President and / or Vice President. The Constitutional Court examines and assesses the DPR's opinion on whether the President and / or the Vice President are working to comply with Article 
7A of the 1945 Constitution of the Republic of Indonesia (UUD NRI 1945). The examination conducted by the Constitutional Court is a judicial process whose decisions are in the form of justices. The outcome of this impeachment process depends very much on the decision of the People's Consultative Assembly in a plenary meeting which is also a political forum, in which the President and / or Vice President can be dismissed or not. The Constitutional Court's decision does not apply to the People's Consultative Assembly, therefore, differences in the decisions of the Constitutional Court and the People's Consultative Assembly in a plenary session that are highly political in nature are very likely to occur. The involvement of the Constitutional Court in the impeachment process varies from country to country. It depends on the system of government in a particular country, it also depends on how much power the Constitution grants to the Constitutional Court in the impeachment process itself. (Tinambunan, 2018)

\section{Research Method}

\subsection{Types of research}

This type of research used by the author is the kind of normative study by way of searching for data and information directly to the respondent or the parties involved in this study legal problems and conduct literature searches.

According to Peter Mahmud Marzuki formulate normative legal research is to find the truth of coherence, is there any rule of law appropriate legal norms and are there any norms that form the command or prohibition in accordance with the principle of huku $\mathrm{m}$ , as well as whether a person acts in accordance with legal norms or legal principles. (Marzuki, 2008)

\subsection{Type of Approach}

Historical researchers used a type of approach (Historical Approach) and approach to legislation (Statue Aprroach) which according to Peter Mahmud marzuki in his study of law namely the approach of the approach Historical (Historical Approach) is carried out within the framework of the history of legal institutions from time to time. Meanwhile, the statutory approach (Statue Aprroach) According to Peter Mahmud Marzuki in his book Normative legal research is a statutory approach method, namely researchers need to understand hierarchy and principles in statutory regulations.

\subsection{Types and sources of legal materials}

In order to solve legal issues and at the same time provide a prescription on what should be, research sources are needed. Sources of legal research can be differentiated into 2, namely research sources in the form of primary legal materials and secondary legal materials, namely as follows:

a. Primary legal materials: These are legal materials that are authoritative in nature, meaning they have authority. Primary legal materials consist of legislation and judges' decisions.

b. Secondary legal material: which is commonly referred to as complementary legal material from primary, namely in the form of all publications of all about law including text books, law dictionaries, legal journals and comments on court decisions. 


\subsection{Legal Material Analysis Techniques}

The data obtained and collected in this study are qualitative data, so that the data analysis technique used also uses qualitative techniques, where the data processing is done deductively, starting from the basics of general knowledge, then examining things that are is specific so that from this analysis process a conclusion is drawn. The approach taken is juridical normative, namely by describing the existing materials as a result of the research. In this normative approach, research is carried out on legal norms that have problems with what is being studied. This kind of approach is carried out by examining the legal reality which is carried out from a juridical perspective that can support this writing activity .

\section{Result and Discussion}

\subsection{The functions and powers of the MPR RI before and after the 1945 Constitution amendment}

Prior to the amendment to the 1945 Constitution, the People's Consultative Assembly (MPR) was constructed as a place for the incarnation of all sovereign people, a place where the president must submit and be accountable for all the implementation of his constitutional duties . in the explanation of the 1945 Constitution prior to the amendment, it was stated that "the president is submissive and accountable to the MPR." From this construction, the People's Consultative Assembly is understood as the highest state institution in which the sovereignty of all Indonesian people is manifested. ( Asshiddiqie , 2010)

According to the provisions of article 3 juntco article 37 of the original 1945 Constitution (before the amendment), the People's Consultative Assembly has the authority to ( i ) enact the Basic Law, (ii) amend the constitution, (iii) elect the president and / or vice president, and (iv) to determine the outline of the MPR's directions given the authority to determine the guidelines (rather than) the State intends to provide working guidelines and guidelines for the preparation of a work program for the president in carrying out his duties, the guidelines (rather than) of the State are needed because The guidelines or policies for the state as stipulated in the 1945 Constitution are very or even too concise and simple. Therefore, in addition to clearer State policies outside the 1945 Constitution ( Asshiddiqie , 2010)

The State objectives in question need to be set forth in the form of provisions regulating with effective binding capacity. Because the position of the MPR itself is higher than that of the president and the House of Representatives, automatically the position of the MPR / S Decree is considered higher than the law. In fact, the MPR / S stipulations which are regulative in nature also have a position as constitutional law, because they are made and stipulated by the same institution that stipulates the constitution. ( Asshiddiqie , 2010)

In the juridical, the Assembly itself as an institution (organ) just be there (exist) when running one of the four powers ( bevoegdheden ) The .. Session of the Assembly can only be implemented to run one of the four above-mentioned authority. However, it should be noted that of the four powers mentioned above, the only one that is routine and periodic is the authority to appoint the president and / or vice president. Regarding the matter is, it should also be noted that: 
a. The inauguration of the President and / or Vice President is not carried out by superiors to subordinates. According to the provisions of Article 9 of the 1945 Constitution, the President and / or the Vice President shall personally pronounce their oath or promise of office in and before the MPR session. The role of the chairman of the MPR session is only to open and close the session. In this way, the inauguration of the president and / or vice president by the MPR is deemed to have been implemented.

b. The MPR session forum as a vehicle for the inauguration of the President and / or vice president is only optional. This means that the inauguration of the president and / or vice president does not absolutely have to be carried out in the MPR session, but can also be carried out in a DPR session or plenary session, if the MPR turns out to be unable to convene even if the MPR and DPR are both unable to meet, then the inauguration can also be done before the leadership of the MPR or DPR witnessed by the leadership of the Supreme Court. ( Asshiddiqie , 2010)

However, apart from the aforementioned matters, the post-reform MPR does not have the authority to stipulate regulations other than amendments to the Constitution. Therefore, from the time the MPR was formed as a result of the 2004 General Election, there would be no longer any legal product containing the governing norms stipulated by the MPR, apart from the amendment to the 1945 Constitution. For example, the MPR would maintain the form of decisions it made as provisions, the nature of such a provision the new version no longer contains the legal norms that are set (Regeling). For example, a decision to dismiss the President and / or Vice President, or a decision regarding the results of the election for the President and / or Vice President to fill a vacancy. Is it possible that the decisions in such a case are stated in the form of a law called a provision.

\subsubsection{K ewena $n$ gan MPR before the amendment 1945}

The provisions in Article 1 paragraph (2) of the 1945 Constitution prior to the amendment stated "Sovereignty is in the hands of the people, and carried out entirely by the People's Consultative Assembly". Even in the 1945 Constitution before the amendment it was said that the president was subject to and responsible for the people's deliberative assembly. This implies the very central position, duties and authority of the MPR where the MPR as the embodiment of the sovereignty of the people who holds the power as determinant, implementation and oversight of the state administration, the position, duties and powers of the MPR before are as follows (Asshiddiqie , 2010) :

\section{Position of the MPR}

The MPR consists of members of the DPR, plus delegates from regions and groups, according to the rules established by law. Thus the MPR is positioned as the incarnation of the entire people and is an institution

\section{Duties and Authorities of the MPR}

In MPR Decree No. 1 / MPR / 1978 it is said that the MPR has the task of determining the Constitution, establishing the GBHN, and electing and appointing the President and Vice President. In addition, the MPR also has the powers, namely:

a) Making decisions, including GBHN, which cannot be overturned by other state institutions, which are implemented by the President

b) Provide an explanation in the form of an interpretation of the MPR decision 
c) Complete the election and appoint the President and Vice President

d) Asking the President to be accountable regarding the implementation of the GBHN and assessing that accountability

e) Change the Constitution

f) Establish MPR rules

g) To determine the MPR leadership elected from and by the members

h) Take decisions regarding members who break the oath / promise of the members . (Quarter, 2011)

\subsubsection{The functions and powers of the MPR RI after the 1945 amendments}

The amendments made by the MPR starting from the first amendment to the fourth amendment have very urgent implications for the composition, duties and powers of the MPR itself, the most fundamental of these changes is the position of the MPR which has been the highest state institution to become a state institution which has the same position as other state institutions, for more details, we will first describe how the MPR after the amendment of the 1945 Constitution is as follows (Triwulan, 2011) :

\section{Position of the MPR}

The MPR is a people's consultative body which is a state institution. With its position as a state institution, the MPR is no longer the highest state institution as stipulated in the 1945 Constitution prior to the amendment .

\section{MPR membership}

Article 2 paragraph (1) of the amended 1945 Constitution states that the MPR consists of members of the DPR and members of the DPD who are elected through general elections and are further regulated by law.

On the basis of the provisions of Article 2 paragraph (1) of the 1945 Constitution the amendment means that the number of MPR members is based on the sum of members of the DPR and DPD members (also regulated in Article 2 of Law No. 22 of 2003). The MPR membership was formalized by a Presidential Decree (Article 3 of Law No. 22 of 2003), the number of DPR members was 550 people (Article 7 (1) of Law No. 22 of 2003), while the DPD members were determined, that the DPD members from each province were appointed 4 people and DPD members should not be more than $1 / 3$ the number of DPR members

\section{Duties and Authorities of the MPR}

In Article 3 of the 1945 Constitution the amendment results that the MPR has the authority to:

a. Amend and stipulate the Constitution

b. Inaugurate the President and / or Vice President

c. To dismiss the President and / or Vice President during their term of office according to the Constitution.

Further duties and authority of the Assembly as stipulated in Law No . 22 of 2003, that the MPR has the duties and authorities: 
a. Amend and stipulate the Constitution

b. Inaugurate the President and / or Vice President based on general elections in the MPR Plenary Session

c. Decide on the DPR's proposal based on the decision of the Constitutional Court to dismiss the President and / or Vice President during their term of office after the President and / or Vice President have been given the opportunity to deliver an explanation at the MPR Plenary Session

d. Inaugurate the Vice President as President if the President dies, resigns, is dismissed, or is unable to carry out his obligations during his term of office

e. Electing the Vice President from the two candidates nominated by the President in the event of vacancies in the position of the Vice President during his term of office at the latest within sixty days

f. To elect the President and the Vice President if both of them quit simultaneously in their term of office, from the two packages of candidates for President and Vice President proposed by a political party or coalition of political parties whose packages of candidates for President and Vice President won the first and second most votes in the previous election, until $\mathrm{h}$ after the term of office is not more than thirty days

g. Establish the Rules of Procedure and Code of Ethics of the MPR

\section{MPR Session}

The MPR meets at least once every five years in the national capital, MPR sessions are valid if attended:

a. at least 3/4 of the number of MPR members to decide on the proposal of the DPR to dismiss the President / Vice President

b. at least 2/3 of the number of MPR Members to amend and enact the Constitution

c. at least $50 \%+1$ of the number of MPR Members at other sessions

\section{MPR decision}

MPR decisions are valid if approved:

a. at least $2 / 3$ of the number of MPR members present to decide the DPR's proposal to dismiss the President / Vice President

b. at least $50 \%+1$ of the total number of MPR members to decide other cases.

Before making a decision with the most votes, firstly attempted to make a decision by deliberation to reach consensus.

MPR decisions include 3 types, namely:

a. Decisions regarding the amendment and stipulation of the Constitution, this decision has legal force as the Constitution of the Republic of Indonesia and does not use the Assembly decision number.

b. The MPR decision, this decision contains matters of a predetermined nature ( beschikking ), has legal force to bind outward and inwardly and use the assembly number 
c. MPR decision, this decision contains internal rules / provisions of the assembly, has legal force in the assembly, and uses the assembly number.

\section{MPR Fittings}

The MPR's apparatus consists of: Leadership, Ad Hoc Committee, and Honorary Body. The MPR leadership consists of a chairperson and 3 deputy chairmen who reflect the DPR and DPD elements who are elected from and by MPR members in the MPR Plenary Session. (Triwulan, 2011) Looking at the comparison, especially its function above, this is a very significant comparison, namely the MPR as the highest institution which has 8 functions, now the post-amendment institution only has 3 functions which are also facultative Regarding the small role of the MPR, Maswardi Rauf wrote that there was a thought that the MPR did not need to be institutionalized. The MPR does not need to be a separate body because it is just a joint session of trials conducted by the DPR and DPD. Furthermore, Rauf stated that the MPR actually only had three functions, namely:

a. Amend and stipulate the Constitution;

b. Inaugurating the President and / or Vice President, and

c. To dismiss the President and Vice President during their term of office (of course, after hearing the DPR's proposal and the fulfillment of other mechanisms that are not easy in the 1945 Constitution). (Asshiddiqie, 2006)

The first and third MPR functions are not routinely performed (rarely). The function of inaugurating the President and Vice President is merely ceremonial, because the MPR is merely conducting a ceremony. It should be noted that it is no longer the MPR that elects the President and Vice President, but the people directly. Therefore, the MPR could not obstruct the inauguration process with a quorum for the presence of their members, let alone the number of votes agreeing / disagreeing with the inauguration. Not to mention the presence of authority-the authority of the House of Representatives (DPR), which emerged after the amendment of the 1945 Constitution that affect the authority of the Assembly 's Consultative Rakyat (MPR) In dismiss the President is now the House could also provide Proposed Dismissal of President To MPR ie, with the advent of 5 Task Supreme Constitutional That ;

a. Material Test Against the Law

b. Deciding State Institution Disputes

c. Dissolution of Political Parties

d. Deciding Election Dispute

e. Impeachment of the President

At the fifth point, namely the impeachment of the president or commonly known as Inpiechment in foreign countries. This is the authority of the Parliament In providing a proposal for dismissal of the president that is the way before giving a proposal for dismissal of the president will be given to this Decision should be tried first in the court of the Constitution, but the trial according to Jimly Assidiki as the first judge in the Court of the Constitution is a session that has the obligation to decide Proposed approval of the House of Representatives is therefore in the Written 5 Kewen an gan but in fact the task of the Court constitutional Being 4 Kewen an gan 1 obligation is 1 obliged to decide Proposed DPR for Dismissal of the President. 
Of the 3 remaining tasks by the MPR after the amendments to the 1945 Constitution, actually they no longer have validity with the presence of the authority of the DPR which is getting higher after the amendment of the 1945 Constitution, so with very minimal duties and functions, many legal experts have argued that this provision Just get rid of the People's Consultative Assembly (MPR).

$\mathrm{P}$ endapat researchers after reading the treatises MPR post amande me $n$ reinforced also by the books of the study the experts one of which is a book mahfud MD of struggle pol $i$ tick and the law turned out to be in effect by political struggles in Indonesia, which will be researchers discussed later in the second problem formulation

\subsection{Political Configuration of the Authority of the MPR as a State institution in Indonesia}

\subsubsection{Political configuration in Indonesia}

This problem was chosen because of the constellation that legal autonomy in Indonesia tends to be weak, especially when it comes to dealing with the political subsystem. Strictly speaking, the concentration of legal energy is always less powerful than the concentration of political energy. ( Rahardjo , 1985) This constellation can be seen from the fact that throughout Indonesia's history, the implementation of functions and law enforcement did not go hand in hand with the development of its structure. It is said that if the program of legal codification and unification is made, the measure of legal structure development has run quite well and is stable because from time to time there is an increase in productivity: but on the other hand it can also be seen that the function of the law tends to decline. (MD, 1999)

It can be said that the legal structure can develop in all political configurations marked by the success of codifying and unification in various fields of law, but the implementation of the function or enforcement of legal functions tends to weaken the re-presence of the People's Consultative Assembly as a state institution, in fact it needs to be questioned again because this institution does not have the more power in the Kewen imagination even today MPR Demanding back its authority on determining guidelines, this is certainly the program MPR in 2020 they urged legal experts through studies law in each area to amend the return Constitution 1945 order so that the authority in re-determining the GBHN is returned to the MPR, this is of course a very strong political push by the MPR without thinking about the existing constitution in Indonesia if that happens then the government in Indonesia will return to what it used to be where the MPR will regulate us through The GBHN provisions it has . (MD, 1999)

\section{Conclusion}

The MPR as the highest institution Before the amendment which has 8 functions, now this institution has only 3 functions after the amendment is facultative. Regarding the small role of the MPR, this thought that the MPR did not need to be institutionalized by looking at the three functions of the MPR after the amendment:

a. Amend and stipulate the Constitution;

b. Inaugurating the President and / or Vice President, and

c. Dismissing the President and Vice President during their term of office)

The first and third MPR functions were not routinely performed. The function of inaugurating the President and Vice President is merely ceremonial, because the MPR is 
merely conducting a ceremony. Consultative Assembly of the People as a state institution it needs to be questioned again because these institutions do not have the more power in the Kewen an gan even at this moment MPR Demanding back its authority on determining guidelines, This is certainly the program MPR In 2020 they urged legal experts through legal studies in each region to re- amend the 1945 Constitution so that the authority to re-determine the GBHN is returned to the MPR, this is of course a very strong political impetus by the MPR without thinking about the existing constitution in Indonesia. If this happens, the government in Indonesia will return like in the past, where the MPR would regulate us through its GBHN decisions

\section{References}

Asshiddiqie, J. (2006). Sengketa Kewenangan Konstitusional Lembaga Negara. Jakarta: Konstitusi Pers.

Asshiddiqie, J. (2010). Perihal Undang-Undang. Jakarta: Raja Grafindo Persada.

Indrayana, D. (2004). 'Negara Hukum Pasca Soeharto : Transisi Menuju Demokrasi VS korupsi. Jurnal Mahkamah Konstitusi.

Marzuki, P. M. (2008). Penelitian Hukum. Jakarta: Kencana Prenada Media Group.

MD, M. (1999). Pergulatan Politik dan Hukum di Indonesia. Yogyakarta: Gama Media.

Prodjodikoro, W. (n.d.). Asas-Asas Hukum Tata Negara di Indonesia. Jakarta: PT. Dian Rakyat.

Rahardjo, S. (1985). Beberapa Pemikiran Tentang Ancangan Antar Disiplin Dalam Pembinaan Hukum Nasional. Bandung: Sinar Baru.

Riyanto, A. (2006). Teori Konstitusi. Bandung: Yapemdo.

Tinambunan, H. S. R. (2018). Reconstruction the Authority Of Constititional Court On Impeachment Process Of President And/Or Vice President In Indonesian Constitutional System. Jurnal Dinamika Hukum, 16(1).

Triwulan, T. (2011). Konstruksi Hukum Tata Negara Indonesia Pasca Amandemen UUD 1945. Jakarta: Pernada Media Group. 